\section{PHARMACEUTICAL POLICY AS A RIGHT AND AS A SERVICE: REFLECTIONS ON POPULATION TRUST.}

Rua Vergueiro, 1855 - $12^{\circ}$ andar

Vila Mariana - São Paulo - SP

CEP 04101-000 - Tel./Fax: (11) 5083-4297

atendimento@sbrafh.org.br/www.sbrafh.org.br

Conselho Diretor

Presidente - Maely Peçanha Favero Retto

Vice-Presidente - Vandré Mateus Lima

Conselho Editorial RBFHSS

Editora-Chefe - Profa. Dra. Elisangela da Costa Lima -Dellamora - UFRJ, RJ, Brazil

\section{Editores Associados}

Profa. Dra. Angelita Cristine Melo - UFSJ - MG, Brazil Prof. Dr. Andre de Oliveira Baldoni - UFSJ MG, Brazil Prof.Dr. Leonardo Regis Leira Pereira - USP-RP SP, Brazi Profa. Dra Luciane Cruz Lopes - UNISO, SP, Brazil Profa. Dra. Maria Rita Garbi Novaes - ESCS/

FEPECS, Brasilia, Brazil

Profa. Dra. Vera Lucia Luiza - ENSP/Fiocruz, RJ, Brazil

\section{Membros do Conselho Editorial}

Prof.Dr.Adriano Max Moreira Reis - UFMG, MG, Brazil Prof.Dr.Ahmed Nadir Kheir - Qatar University, Doha, Qatar Prof.Dr. Alberto Herreros de Tejada - Majadahonda, Spain Profa. Dra. Carine Raquel Blatt - UFCSPA, RS, Brazil Profa. Dra. Claudia Garcia Osorio de Castro ENSP/ Fiocruz, RJ, Brazil

Prof. Dr. David Woods - University of Otago, New Zealand Profa. Dra. Dayani Galato - UnB, Brasilia, Brazil

Prof. Dr. Divaldo Pereira Lyra Junior - UFS, SE, Brazil Prof. Dr. Eduardo Savio - Montevideo, Uruguay Profa. Dra. Helena Lutescia Luna Coelho, UFC, CE, Brazil Profa. Dra. Inés Ruiz Álvarez - Universidad de Chile, Chile Prof. Dr. João Carlos Canotilho Lage, Coimbra, Portugal Profa. Dra. Lúcia de Araújo Costa Beisl Noblat- UFBA BA, Brazil

Profa. Dra. Marcela Jirón Aliste, Universidad de Chile, Chile Prof. Dr. Marcelo Polacow Bisson, Sao Paulo, SP, Brazil Profa. Dra. Maria Teresa Ferreira Herdeiro, Universidade de Aveiro, Portugal

Prof. Dra. Marta Maria de França Fonteles UFC, CE, Brazi Profa. Dra. Selma Rodrigues de Castilho, UFF, Brazil Profa. Dra. Sonia Lucena Cipriano, Sao Paulo, SP, Brazil

Diagramação:Liana de Oliveira Costa

\section{Missão}

Publicar artigos científicos que contribuam para o avanço do conhecimento da Farmácia Hospitalar e da assistência farmacêutica nos demais serviços de saúde, que apresentem tendências conceituais, técnicas, sociais e políticas que poderão ser utilizada para fundamentar açōes dos profissionais da área Os artigos serão avaliados por, no minimo, dois consultores com expertise e producao científica na área de conhecimento da pesquisa.

Periodicidade: Trimestral

Exemplares: 3.000

Acesso aberto pelo website http:// www.sbrafh.org. $\mathrm{br} / \mathrm{rbfhss}$ /index/edicoes/

Circulação é gratuita para os associados da SBRAFH. Outros interessados em assinar a revista poderão efetuar seu pedido junto à Secretaria da SBRAFH - Telefone: (11) 5083-4297 ou pelo e-mail: atendimento@sbrafh.org.br.

Valores para assinaturas anuais (4 edições):

- Brasil: R\$200,00

- Exterior: U\$ 150

Recently, the National Survey on Access and Rational Use of Medicines (PNAUM) has shown, in numbers, important advances in access to medicines in Brazil. According to the study, $94.3 \%$ of Brazilians with some of the chronic diseases surveyed by PNAUM, and who had a prescription for medication to control the disease, had access to and used the prescribed medication. Of the Brazilians with chronic diseases, $47.5 \%$ obtained all the medicines they needed for free. When only hypertensive patients were analyzed, $72.0 \%$ of them received the medicines in SUS or Popular Pharmacy, and only $25.7 \%$ of hypertensive Brazilians paid for the drug (Bermudez; Barros 2016).

These results corroborate the evidence from the Participatory Evaluation of the 10 Years of the National Pharmaceutical Policy which found in 2014 that the perception of health professionals and patients
As normas para publicação de artigos técnicos estão na página principal. seu cadastro de autor e confirmá-lo através de email enviado. Os artigos assinados são de inteira responsabilidade de seus autores e não refletem necessariamente a opiniāo da Sociedade Brasileira de Farmácia Hospitalar e Serviços de Saúde.

Os anúncios publicados também são de inteira responsabilidade dos anunciantes.

Esta Revista é impressa com apoio cultural do Laboratório Cristália de Produtos Químicos Farmacêuticos LTDA.
Os artioos devem ser enviados através deste site após criar 
was that access to medicines and pharmaceutical services in Brazil have increased significantly. Legal and normative frameworks were consolidated, giving structure to develop pharmaceutical services in the context of the health policy. However, there are also perceptions of barriers to access to medicines (mainly in the north and northeast regions) and deficiencies in the management of pharmaceutical care, especially at the municipal level. Concerns about the political and economic sustainability of public policies were also highlighted in the evaluation (Faraco et al, 2017).

Reviewing evidence from studies published in the last years of the Research Group on Pharmaceutical Policies and Services of UFSC on trajectories and experiences of patients in access to high-priced drugs (via the Specialized Component of Pharmaceutical Assistance or through the litigation process), and reconsidering them now in the perspective of trust in the health system, we can find a cruel picture of pilgrimages, humiliation, anguishes, and the understanding that in certain circumstances, access to medicines is a favor, not a right (Leite, Mafra 2010). In others, there is the perception that "they [the government) put difficult procedures, so that the person gives up and does not continue" (Carvalho, Leite 2014), that drugs are not lacking, but that there is too much bureaucracy preventing access to medicines (Rover et al 2016a; 2016b).

We are experiencing in Brazil at the same time, the great development of pharmaceutical services, both in public and private institutions. For some of these services, there is already scientific evidence of positive health outcomes and patients satisfaction. Undoubtedly, this is an important move for the population to have a reference to the greater development of trust in the pharmaceutical professional and in the institutions (health units, pharmacies) as legitimate health services of greater social value. However, there seems to be a hyper-estimation of the capacity to obtain impactful and sustainable health outcomes from specific and isolated pharmaceutical services (not integrated in health care process). The risk we face in this case is that we have a negative impact on people's conditional trust in pharmaceutical services and professionals.

In any case, the legitimacy and valuation of pharmaceutical policy as a right of people and a legitimate social good is defined by access to pharmaceutical products and services as a continuous whole. This complete access configuration is capable of developing for people the assurance that they will have appropriate treatment for their health problems and that they can rely on this health sector - both in the quality and effectiveness of the products and in the ability to obtain them and also the services that will be offered with the medicines.

We are living, therefore, a period of great relevance for our sector. In 2019 we will hold the 16th National Health Conference - and the municipal stages and thematic meetings are already beginning to take shape. The results of the Preparatory Meetings and the 8th National Symposium on Science, Technology and Pharmaceutical Policy (held in December 2018 at FIOCRUZ's headquarters in Manguinhos) are already available through the Rio de Janeiro Charter (FIOCRUZ, 2018 and should guide our participation in the stages of the Conference, leading the debate on pharmaceutical policy and practices and the role of pharmacists and pharmacies to society as a whole. It is time for us to engage in the defense of the right of people to pharmacy - from product to services, and build? the relationship of trust with Brazilian society.

Silvana Nair Leite is pharmacist, Doctor in Public Health, professor at Universidade Federal de Santa Catarina and head of Federação Nacional de Farmacêuticos e da Federação Nacional dos Farmacêuticos (FENAFAR). Michael Calnan is sociologist, professor at School of Social Policy, Sociology and Social Research from Universidade of Kent.

\section{REFERENCES}

1. BERMUDEZ, Jorge Antonio Zepeda e BARROS, Marilisa Berti de Azevedo. Perfil do acesso e da utilização de medicamentos da população brasileira - contribuições e desafios da PNAUM - Inquérito Domiciliar. Rev. Saúde Pública [online]. 2016, vol.50, suppl.2 [citado 2019-01-25], 2s. Disponível em: http://www.scielo.br/scielo.php?script=sci_arttext\&pid=S0034-89102016000300201\&lng=pt\&nrm=iso

2. BROWN Patrick and CALNAN Michael Trusting on the Edge; Managing uncertainty and vulnerability in the midst of serious mental health problems policy press 2012,p138

3. CALNAN, Michael; ROWE, Rosemary. Trust Matters in Healthcare. Open University Press, 2008. 224p 